\title{
An Empirical Modelling of New Zealand Hospitality and Tourism Stock Returns
}

\author{
Christine Lim ${ }^{1}$ and Felix Chan ${ }^{2}$ \\ ${ }^{1}$ Nanyang Business School and Institute on Asian Consumer Insight, Nanyang Technological University, Singapore 639798 \\ ${ }^{2}$ Curtin Business School, Curtin University, Perth 845, Australia
}

Correspondence should be addressed to Christine Lim; christinelim@ntu.edu.sg

Received 27 December 2012; Accepted 17 January 2013

Academic Editors: J. H. Haslag, J.-L. Hu, and B. M. Tabak

Copyright (C 2013 C. Lim and F. Chan. This is an open access article distributed under the Creative Commons Attribution License, which permits unrestricted use, distribution, and reproduction in any medium, provided the original work is properly cited.

\begin{abstract}
This paper examines the factor risk premiums of stock returns for the hospitality and tourism companies in New Zealand. The Arbitrage Pricing Theory (APT) approach is used to investigate the expected return for stock portfolio with respect to market, macro (i.e., money supply and discount rate), and tourism factor sensitivities. Monthly stock prices, market index, tourism, and macroeconomic data are used in the study. The results indicate that the risk premiums for international tourism demand and term premium (proxy for discount rate) are positively significant at the $5 \%$ level. A one unit increase in tourist arrival sensitivity would result in expected return increase of 10 to 17 percentage point. Similarly, a one unit increase in term premium can increase hospitality-tourism expected returns by 0.2 percentage point. However, the findings for the money supply factor are not significant. As the study shows that investors face high positive tourism demand risk, it is imperative for firms and policymakers in New Zealand to promote inbound tourism through effective marketing and management. This in turn can provide high expected returns and create shareholder value for investors.
\end{abstract}

\section{Introduction}

Tourism is travel for recreational/leisure, visiting friends and relatives (VFR), or business purposes. It is vital for the global economy in terms of the production of goods and services, income, and employment generation in the service industries associated with tourism. The real average annual growth of world tourism exceeded the global economic growth during the period 2004-2007 [1]. In 2008 and 2009, international travel demand experienced a tremendous slowdown. Resurgence in international tourist arrivals was evidence of tourism recovery in 2010. Tourism contribution to total global GDP in 2011 was $9 \%$ or US\$6 trillion [2].

The tourism industry comprises the full scale of businesses which range from large stock exchange listed corporations to small owner-operators. Hospitality business as defined by Hayes and Miller [3, page 5] is "an organization providing food, beverages, lodging, travel or entertainment services to people away from their homes." As the goal of a company is to increase the value of the firm for its shareholders, investors often assess the performance of the firm based on their stock return and variability of return. The stock returns of individual companies and market are commonly used because they are regarded as good indicators of business activities and the data/information are easily available. Chen et al. [4] argued that variations in stock prices and expected returns can be explained by the health of the macroeconomy. If business conditions are expected to improve (deteriorate), company earnings are likely to increase (decrease), and this will have a positive (negative) effect on stock prices [5]. Invariably, studies have shown that macroeconomic factors (such as GDP growth, changes in money supply, unemployment rate, exchange rate, and inflation rate) have significant influence on the fluctuations in stock returns.

The Arbitrage Pricing Theory has been used extensively in the economics and finance literature to explain stock returns. However, this empirical model has not been applied in hospitality and tourism research. The objective of this paper is to examine the factor risk premiums of hospitality and tourism stocks in New Zealand. We use the Arbitrage Pricing Theory approach to investigate the expected return for stock 
portfolio with respect to market, macro, and tourism factor sensitivities. Our sample includes hospitality and tourismrelated companies listed in the New Zealand Stock Exchange (NZX), namely, Auckland International Airport, Air New Zealand, Millennium \& Copthorne Hotels, New Zealand Experience, Restaurant Brands, SkyCity Entertainment, and Tourism Holdings. These companies are associated with restaurant/food service, lodging, entertainment, transportation, and so forth. Some of these companies are also listed in the benchmark NZX 50 Index for New Zealand equities, which comprises stocks in the top fifty largest companies on the New Zealand Stock Exchange by market capitalization. The NZX 50 is a gross index, weighed according to the "free float" market capitalization of each company based on the percentage of stocks available for trading. The seven hospitality and tourism-related companies under study belong to the $\$ 16$ billion services sector of the New Zealand market.

The plan of the remainder of the paper is as follows. In Section 2, we examine the risk-return performance of the selected hospitality and tourism companies for the period 1999 to 2012. Section 3 provides a review of related studies in the hospitality and tourism literature. The methodology used in the study is discussed in Section 4, and the results are presented in Section 5 with some concluding remarks in Section 6. Seasonally unadjusted monthly stock prices, market index, and tourism and macroeconomic data from 1999(3)-2012(9) are used. They are obtained from Datastream, Statistic New Zealand, and the Reserve Bank of New Zealand.

\section{Hospitality and Tourism Companies in New Zealand}

Auckland International Airport (AIA) was listed in the New Zealand Stock Exchange in 1998. The airport is the busiest international gateway in New Zealand. More than $70 \%$ of all international passengers arriving and departing from New Zealand use the Auckland Airport, which handles over 13 million passengers per year. International tourism demand for New Zealand was adversely affected by events such as the September 11 terrorist attacks in the USA, collapse of Ansett Australia which affected Air New Zealand (AIA's major customer), Bali bombings, Iraq War, SARS outbreak, and the 2008 financial crisis. Despite these problems which significantly affected international aviation, AIA still managed to achieve increase in revenue, thus proving its resilience to adversities [6]. AIA was estimated to generate about NZ\$19 billion to the New Zealand economy in 2006; and the contribution is expected to grow to $\$ 26-\$ 32$ billion in 2021 [7].

Air New Zealand (AIR), formerly owned by the New Zealand Government, was privatized in 1987 and it was subsequently listed on the New Zealand Stock Exchange in 1989. In 2000, Air New Zealand acquired full ownership of Ansett Australia. Ansett was a larger airline than Air New Zealand before the merger, and it operated domestic flights within Australia and to several destinations in Asia. The large decrease in AIR stock prices in 2001 was due to the financial collapse of Ansett one day after the terrorist attacks in the USA. The demise of Ansett required the New Zealand Government to bail its flagship carrier out of the financial disaster. Inevitably, the public sector has again become the largest shareholder of Air New Zealand. The airline won the Air Transport World award for 2010. Plunging profits have forced Air New Zealand to embark on cost-cutting measures and large discounting to reduce capacity in response to the downturn in passenger numbers especially on long haul routes [8-10].

Millennium \& Copthorne Hotels was listed on the New Zealand Stock Exchange in 1985. It runs thirty hotels in New Zealand under three operating brands: Millenium, Copthorne, and Kingsgate (MCK). The company is the largest owner-operator hotels in New Zealand, with properties in all major cities across the north and south islands [11, 12]. Restaurant Brands Limited (RBD) is the franchise holder of KFC, Pizza Hut, and Starbucks Coffee in New Zealand. Currently, RBD operates over 200 stores, with KFC as the core focus of the company. KFC is also the most competitive and profitable of the three brands [13].

New Zealand Experience Limited, formerly known as Mount Cavendish Gondola Co. Limited, was listed in 1991. Following the acquisition of Auckland Rainbow's End theme park in 1995, the company's name was changed to New Zealand Experience Limited to reflect its diverse business. The company provides entertainment services in the form of amusement rides and various attractions for the public, corporate functions, school, and youth groups $[14,15]$. SKYCITY Entertainment Group Limited is a leading entertainment and gaming business. In New Zealand, it operates monopoly casinos in Auckland, Hamilton, Christchurch, and Queenstown. The company also operates restaurants and bars, luxury hotels, convention centres, and cinemas alongside its core business [16].

Tourism Holdings Limited was established in 1986 and the company was originally known as the Helicopter Line Limited, specialising in scenic flights in New Zealand's South Island. Following major business acquisitions and expansion in New Zealand and overseas, the company changed its name to Tourism Holdings Limited (THL) in 1996 to reflect its diverse tourism operations. Its operations in New Zealand include car and motorhome rentals, a specialist caravan and motorhome manufacturing, backpacker transport, and tourism activities. Low interest rates have allowed the company to diversify its range of tourism offerings. However in 2008, THL started to restructure its business by concentrating on its core activities in providing mobile tourist accommodation and disposed its noncore assets for debt consolidation in the challenging business operating environment. Restructuring, discontinued activities, divestments, and downturn in overseas visitor arrivals have negatively impacted the company's earnings $[17,18]$.

2.1. Risk-Return Performance of Companies. The rate of return on each stock is defined as the proportional change in the monthly stock price (or the monthly percentage return). Figure 1 shows the stock returns of the seven selected hospitality and tourism companies for the period 1999 to 
TABle 1: Descriptive statistics of Hospitality and Tourism Companies Monthly Stock Returns, 1999(3)-2012(9).

\begin{tabular}{lccc}
\hline Stock return & Mean & Standard deviation & Normality \\
\hline Auckland International Airport (AIA) & 0.685 & 5.82 & $2.38^{*}$ \\
Air New Zealand (AIR) & -1.476 & 11.88 & 7.55 \\
Millenium \& Copthorne Hotels (MCK) & 0.168 & 13.85 & $9.64^{*}$ \\
New Zealand Experience (NZE) & 1.106 & 7.41 & 98.23 \\
Restaurant Brands (RBD) & 0.358 & 6.25 & $6.52^{*}$ \\
Sky City Entertainment (SKC) & 0.576 & 10.06 & 14.56 \\
Tourism Holdings (THL) & -0.402 & 6.86 \\
\hline
\end{tabular}

Note: ${ }^{*}$ indicates $5 \%$ significance level.
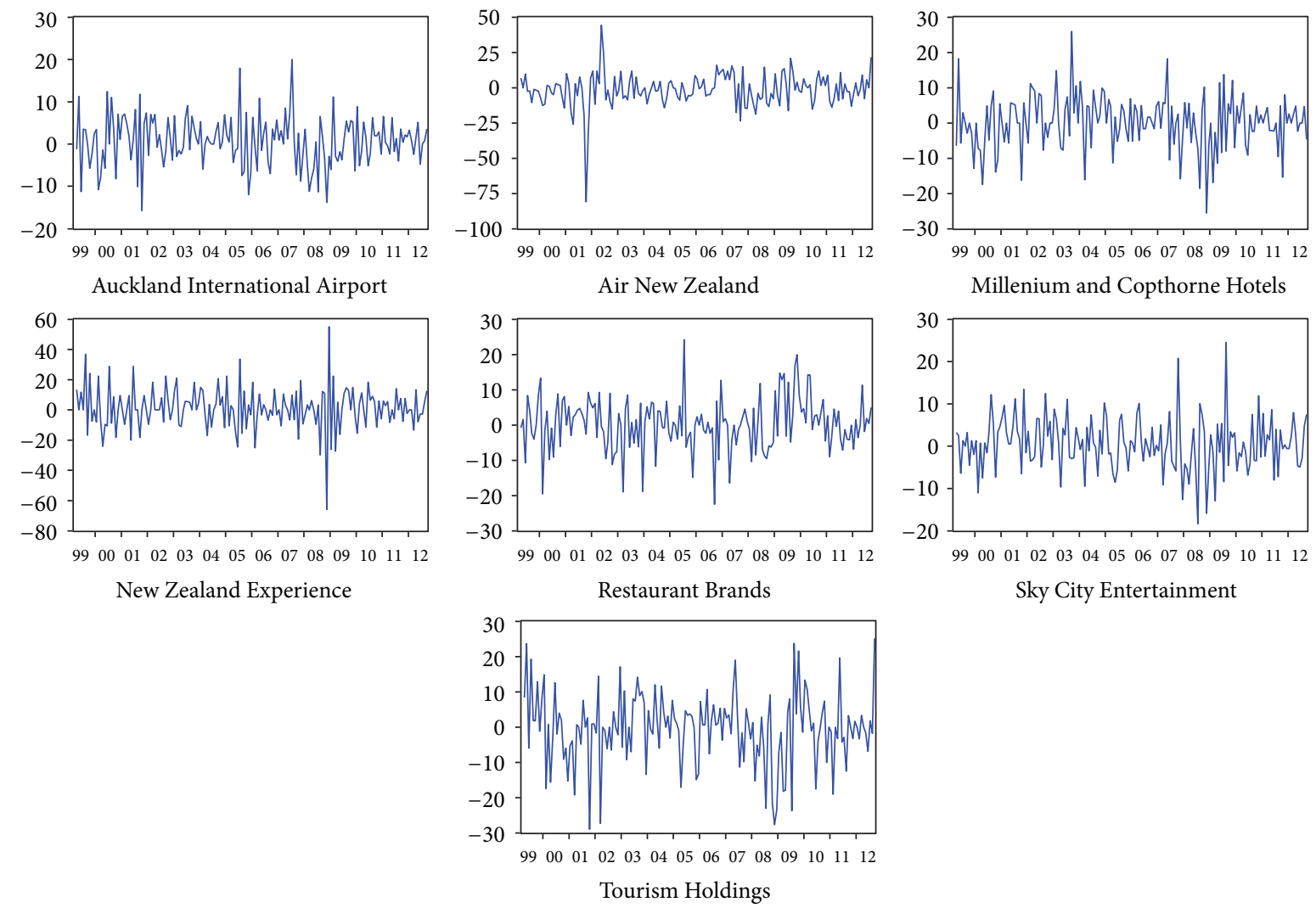

FIGURE 1: Monthly returns (\%) for hospitality and tourism companies, 1999(3)-2012(9).

2012. Summary statistics for their rates of return are given in Table 1. During this period, the average monthly returns for all the stocks are less than $1 \%$ except for NZE, with negative returns for AIR and THL. The average monthly returns range from a high of $1.1 \%$ for NZE to a low of about $-1.5 \%$ for AIR stock. Variance is a well-known measure of dispersion about the mean. The risk of return as measured by the standard deviation of return shows that NZE and AIA have the highest and the lowest risk, respectively. It is also worth mentioning that all the hospitality and tourism stocks have higher risks of return than the overall market's (given by NZX All Stock Index) standard deviation of 3.7 percent. A positive tradeoff between risk and return is only evident in NZE stock, whereas AIR stock displays relatively high risk and negative return.
Using the Jarque-Bera test for normality, the null hypothesis of a normal distribution of return is not rejected for AIA, MCK, and RBD at the 5\% significance level.

While Table 1 shows the risk of a stock as measured by the dispersion of its return distribution, another way to examine risk is to calculate the stock beta. According to the Capital Asset Pricing model (CAPM), the only factor that is important in influencing expected returns is the market return. Specifically, the expected return of a stock is determined by the risk-free rate of return (which is generally measured as the yield on Treasury bills), the stock beta, and the expected market return. The relationship can be written as follows:

$$
\bar{R}_{i}=R_{f}+\beta_{i}\left(\bar{R}_{m}-R_{f}\right)
$$


TABLE 2: Beta estimates for hospitality and tourism companies, 1999(3)-2012(9).

\begin{tabular}{lccc}
\hline Company & Beta & $t$-stat & $R^{2}$ \\
\hline Auckland International Airport (AIA) & 0.876 & 8.43 & 0.31 \\
Air New Zealand (AIR) & 1.250 & 5.32 & 0.15 \\
Millenium \& Copthorne Hotels (MCK) & 0.561 & 3.60 & 0.08 \\
New Zealand Experience (NZE) & 0.142 & 0.48 & 0.001 \\
Restaurant Brands (RBD) & 0.645 & 4.29 & 0.10 \\
Sky City Entertainment (SKC) & 1.081 & 10.48 & 0.41 \\
Tourism Holdings (THL) & 1.573 & 8.93 & 0.33 \\
\hline
\end{tabular}

where $\bar{R}_{i}=$ expected return of stock $i ; R_{f}=$ risk-free rate of return; $\bar{R}_{m}=$ expected return on market portfolio; $\beta_{i}=$ beta or systematic risk of stock $i$ to be estimated.

In other words, the expected return of stock $i$ is the riskfree rate plus a risk premium given by $\beta_{i}\left(\bar{R}_{m}-R_{f}\right)$. The systematic risk as denoted by $\beta$ is the coefficient of a stock which measures the responsiveness of its rate of return to that of the overall market. This is given by the covariance of stock $i$ with the market portfolio as shown below:

$$
\beta_{i}=\frac{\operatorname{cov}\left(R_{i} R_{m}\right)}{\sigma^{2}\left(R_{m}\right)},
$$

where $R_{i}=$ return of stock $i ; R_{m}=$ return of market portfolio; $\operatorname{cov}\left(R_{i} R_{m}\right)=$ covariance of stock $i$ return with the market return; $\sigma^{2}\left(R_{m}\right)=$ variance of the market return.

The New Zealand benchmark NZX All Stock Index is the proxy for the market portfolio. Using the CAPM, the beta estimates for the seven companies are given in Table 2. All the stocks have positive and significant betas at the $5 \%$ level except for NZE. The estimated beta values range from 0.56 to 1.57 (excluding NZE). AIR and THL have higher market risk than AIA, MCK, and RBD, as shown by their respective betas. This is consistent with the risk of return findings in Table 1. Moreover, Table 2 shows that AIA, MCK, and RBD are less responsive to fluctuations in the market return (with beta values less than one). SKC, which has a relatively low risk of return, is however quite responsive to changes in the market return. What is also important is to examine the responsiveness of these stocks to other explanatory factors.

\section{Literature Review}

Following the pioneering work by Ross [19] and Chen [20], many studies which examine the macroeconomic determinants of stock returns applied the multifactor Arbitrage Pricing Theory model (see for instance [4, 21-24]). But very few similar studies have been undertaken in the past to analyse the effects of macroeconomic factors on tourism and hospitality stock returns [5, 25-31].

Barrows and Naka [25] examine the relationship between five selected macro variables and stock returns of hospitality (restaurant and lodging) companies in the US. The latter is taken from the restaurant and hotel/motel sectoral stock indexes in the Standard and Poor 500 (S\&P 500) valueweighted Index. According to their study, inflation rates, money supply, and domestic consumption growth rates are significant explanatory factors of hospitality stock returns. Wong and Song [31] use the vector autoregressive modelling approach to investigate the relationship between hospitality (restaurant, lodging and casino) stock indices and a number of macroeconomic variables in the US. Their findings show that the interest rate variable is the major factor in explaining fluctuations in the stock indices. According to Chen [30], the discount rate and the federal funds rate of the US monetary policy have different impact on hospitality stock returns. There is no significant relationship between hospitality stock returns and changes in the discount rate. However, the study shows a significant link between restaurant stock returns and changes in the federal funds rate.

Chen et al. [26] and Chen [5, 27-29] analyse the stock returns of hospitality and tourism firms in Taiwan and China. In their study which documents the relationship between stock returns, macro, and nonmacro factors, Chen, et al. [26] find that changes in money supply and unemployment rate have significant impact on Taiwanese hotel stock returns. The latter is also affected by nonmacro factors, namely, domestic and international events. They include political events (the first and second democratic presidential elections in Taiwan, the September 2001 terrorist attacks in the US, and the Iraqi War in 2003), natural disasters (the 1999 earthquake and the 2003 SARS outbreak in Taiwan) and international events (the 1997 Asian financial crisis and several mega sports events). A similar study undertaken in Chen [28] for hotel stock returns in China also includes international tourism demand as an explanatory variable.

Chen [27] investigates the impact of macro factors under restrictive and expansive monetary environment on hotel stock investment in Taiwan. The author argues that investors tend to increase (decrease) their holdings of hotel stocks during expansive (restrictive) monetary periods. Chen [5] conducts cointegration and causality tests and finds support for a long-term relationship between business conditions and financial performance (as measured by stock returns) of tourism firms in China and Taiwan. Chen [29] examines the impact of economic and tourism factors on the corporate performance of Taiwanese hotels using panel regression techniques. Stock return is one of the measures of corporate performance used in the study. No significant relations are found for stock return performance, economic and tourism factors.

Other studies examine the relationship between nonmacro factors and stock returns such as the impact of 
acquisition activity [32], the influences of legislation actions [33], government intervention in tourism diversification [34], announcement/news on new hotel opening [35], SARS outbreak [36], business cycle, and firm-specific characteristics [37-39].

Unlike the aforementioned tourism studies, we use the two-step Arbitrage Pricing Theory approach to examine the risk premiums of hospitality-tourism stock portfolio in relation to market, macro, and tourism factors. Since our sample comprises small and large hospitality and tourism firms in New Zealand, this produces a spread of average returns and estimates for the variables under study. Moreover, we use an individual stock regression approach as this procedure helps avoid the error-in-variables problem [40].

\section{Methodology}

4.1. Model Specification. In contrast to the single-factor CAPM in which stock returns are explained solely by market returns, the Arbitrage Pricing Theory (APT) model by Ross [19] hypothesizes that stock returns are affected by a range of exogenous variables. According to APT, stock returns are influenced by systematic risks in the economy which affect all stocks to some degree. The linear relationship between stock returns and explanatory factors can be expressed as follows:

$$
R_{i}=a_{i}+b_{i 1} F_{1}+b_{i 2} F_{2}+\cdots+b_{i k} F_{k}+\varepsilon_{i},
$$

where $R_{i}$ is the return on stock $i(i=1, \ldots, n)$; the intercept $a_{i}$ is the expected return to stock $i ; F_{1}, F_{2}, \ldots, F_{k}$ are the common explanatory factors affecting all stock returns; $b_{i 1}, b_{i 2}, \ldots, b_{i k}$ indicate the sensitivities of return on stock $i$ (also called beta or factor loadings) to each unit of increase in the explanatory factors; and $\varepsilon_{i t}$ is a random independent and identically distributed error term. We assume the following:

(i) factors have zero mean: $E\left[F_{k}\right]=0$;

(ii) factors are uncorrelated: $E\left[F_{k} F_{m}\right]=0$ for all $k$ and $m$;

(iii) disturbance term has a zero mean and constant variance: $E\left[\varepsilon_{i}\right]=0, E\left[\varepsilon_{i}^{2}\right]=\sigma_{i}^{2}$, respectively;

(iv) disturbance term is uncorrelated across different stocks: $E\left[\varepsilon_{i} \varepsilon_{j}\right]=0$ for all $i$ and $j$, where $i \neq j$;

(v) disturbance term is uncorrelated with the explanatory factors: $E\left[\varepsilon_{i} F_{k}\right]=0$ for all $i$ and $k$;

(vi) number of explanatory factors cannot exceed the number of stocks under consideration $(k<n)$.

Based on the above assumptions, (3) can be rewritten as

$$
R_{i}=E\left[R_{i}\right]+b_{i 1} F_{1}+b_{i 2} F_{2}+\cdots+b_{i k} F_{k}+\varepsilon_{i} .
$$

The model shows that stock return has three components:

(i) its expected return $E\left[R_{i}\right]$ which reflects the effects of the predicted values of factors;

(ii) its unexpected return due to new information about the factors;

(iii) an error term.
If $F_{1}, F_{2}, \ldots, F_{k}$ have a value of zero, then each $n$ individual stock has return equal to its expected value $E\left[R_{i}\right]$ and the error term. The model shows how stock return can deviate from its expected value due to sensitivities to a number of explanatory factors and firm-specific events (captured by the error term). As the explanatory factors represent priced risk, investors require additional return for bearing systematic factor risk. These factors can be market and macroeconomic variables, while firm specific events (e.g., strike, defect product recall, etc.) generate unsystematic or idiosyncratic risk.

Investors are assumed to be homogeneous and they can form a well-diversified portfolio that eliminates stock-specific risk. To form an arbitrage portfolio, it is necessary that the portfolio weights $(w)$ sum to zero: $\sum_{i=1}^{n} w_{i}=0$. The return on portfolio is given by

$$
\begin{aligned}
R_{p}= & \sum_{i=1}^{n} w_{i} R_{i}=\sum_{i=1} w_{i} a_{i}+\sum_{i=1} w_{i} b_{i 1} F_{1}+\sum_{i=1} w_{i} b_{i 2} F_{2}+\cdots \\
& +\sum_{i=1} w_{i} b_{i k} F_{k} .
\end{aligned}
$$

To obtain a risk-free portfolio, it must earn zero return (i.e., $\left.\sum_{i=1} w_{i} b_{i 1}=0 \cdots \sum_{i=1} w_{i} b_{i k}=0\right)$ and (5) becomes:

$$
R_{p}=\sum_{i=1}^{n} w_{i} E\left(R_{i}\right)=0 .
$$

The equilibrium expected return of a stock is linearly related to the factor sensitivities of the portfolio:

$$
E\left[R_{i}\right]=\lambda_{0}+\lambda_{1} b_{i 1}+\lambda_{2} b_{i 2}+\cdots+\lambda_{k} b_{i k} .
$$

The regression coefficients, $\lambda_{1}, \lambda_{2}, \ldots, \lambda_{k}$, are risk premiums which correspond to the factors $F_{1}, F_{2}, \ldots, F_{k}$. (Detailed discussion of the algebraic developments is given in [41].) If there is a risk-free stock, then $\lambda_{0}$ is the return on the risk-free stock which has no sensitivity to the factors. Hence, $\lambda_{0}$ is the risk-free rate $\left(\lambda_{0}=R_{f}\right)$ and (7) can be rewritten in the form of excess return:

$$
E\left[R_{i}\right]-R_{f}=\lambda_{1} b_{i 1}+\lambda_{2} b_{i 2}+\cdots+\lambda_{k} b_{i k} .
$$

Hence, the APT model is given by

$$
E\left(R_{i}\right)=R_{f}+\sum_{k=1}^{K} b_{i k} \lambda_{k} .
$$

Equation (8) shows that excess return is a linear combination of factor risk premiums. The factor premium can be interpreted as the expected return on a portfolio in excess of the risk-free rate for a portfolio with unit sensitivity to factor $k$ and zero sensitivity to all others. It is worth noting that a factor risk premium can be negative [42].

We will use the APT approach to analyse the expected return on a portfolio of hospitality-tourism stocks in New Zealand, which is built upon estimates of the $b_{i k}$, the sensitivities of return on stock $i$ (see (9)). The choice of explanatory 
variables that might affect returns is guided by economic theory and data availability. Unlike stock prices which are available on a daily basis, no higher frequencies than monthly data are available for tourism and some macroeconomic variables. (Data limitation has meant that several obvious choices such as GDP, industrial production, the CPI, and unemployment rate are not available at the monthly frequency in New Zealand.)

4.2. Data and Variables Used. The seminal work by Roll and Ross [43] and subsequent studies provide evidence of three to five factors used for the APT [40]. We hypothesize that the equilibrium expected returns of hospitality-tourism stocks are linearly related to the factor sensitivities of market, macro (namely, money supply and discount rate), and tourism demand variables. The factors chosen are broadly similar to those used in $[4,21,23,27,30]$, among others.

While the inclusion of the market variable is a common practice in the economics and finance literature, this is not the case in past tourism studies which examine the influences of macroeconomic and tourism factors on stock returns. As investors tend to hold diversified portfolios (as measured by the market index) to reduce their risks, we expect movements in the hospitality and tourism stocks (like other common stocks) to be affected by market return. The NZX All Stock index is used as a proxy for the market variable. It is a market value-weighted portfolio of all existing stocks in the New Zealand Stock Exchange. Given the importance of tourism exports to the New Zealand economy, it is plausible that the risk and expected return of hospitality-tourism stocks are associated with inbound tourist flows to New Zealand. Hence, it is appropriate to include the international tourism demand variable in the model specification.

Stock returns are affected by monetary policy which is the deliberate attempt by the Reserve/Central Bank to influence money supply and interest rates in the economy. Expansionary (contractionary) monetary policy or increases (decreases) in the amount of money in circulation could stimulate (deflate) the economy and higher (lower) stock prices due to lower (higher) interest rates or costs of borrowing. The indirect link between monetary policy, economic activity, and stock returns has been discussed extensively by $[44,45]$. We used M1 as a proxy for money supply. Money supply M1 includes notes and coin held by the public plus chequeable deposits, minus interinstitutional chequeable deposits and central government deposits.

Stock returns are also influenced by the discount rate which affects investors' perception of risk. Past studies have used changes in Treasury-bill yield (proxy for expected inflation) and changes in yield spread between Treasury-bonds and Treasury-bills $[4,21,23]$. These variables are related to the discount rate. We used the 90-day bank bill rate, the term structure of interest rates, and the official cash rate as proxies for the discount rate. The term structure of interest rates or term premium is defined as the difference between longand short-term interest rates. The proxy variables used are the government 10-year and 1-year bond rates, respectively. The official cash rate (OCR) is the alternative proxy for the discount rate given that it is a more conventional monetary

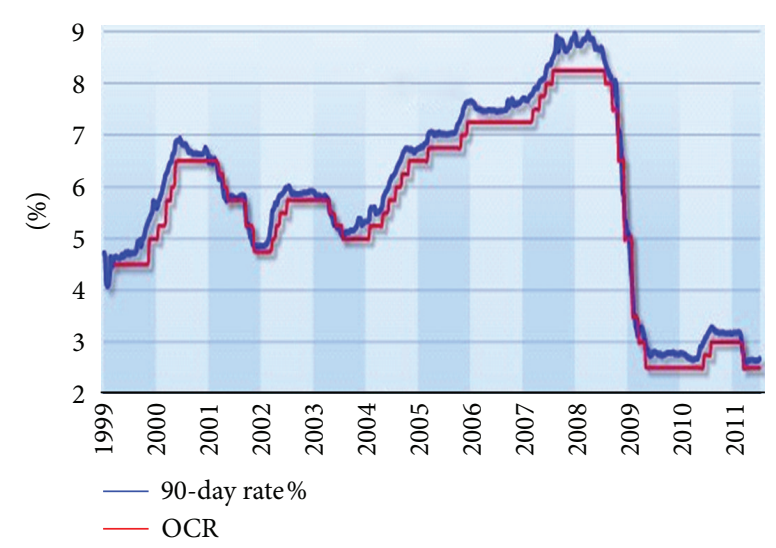

FIGURE 2: Official cash rate and 90-day bank bill rate weekly averages, 1999-2011/2011. source: [46].

tool used to influence the level of economic activity in New Zealand. Moreover, market interest rates are generally held around the Reserve Bank's OCR level [46]. The OCR was introduced in March 1999. Figure 2 shows the average weekly rates of the 90-day bank bill and OCR from 1993 to 2011.

The general linear regression model for stock return to be estimated is

$$
R_{t}=\alpha+\beta_{1} \mathrm{mkt}_{t}+\beta_{2} \Delta \mathrm{ms}_{t}+\beta_{3} \Delta \mathrm{dr}_{t}+\beta_{4} \Delta \text { int_tour }_{t}+\varepsilon_{t},
$$

where $R_{t}=$ stock return at time $t ; \mathrm{mkt}_{t}=$ return of market portfolio at time $t ; \Delta \mathrm{ms}_{t}=$ change in money supply at time $t$; $\Delta \mathrm{dr}_{t}=$ change in discount rate at time $t ; \Delta$ int _tour $_{t}=$ change in international tourism demand in New Zealand at time $t ; \varepsilon_{t}=$ independently distributed random error term, with zero mean and constant variance $\sigma_{u}^{2}$ at time $t ; \alpha, \beta_{1}, \ldots, \beta_{4}$ $=$ parameters to be estimated.

The return on each stock during period $t$ does not include dividends which are only reported semiannually in New Zealand. We computed the monthly stock return by taking the change in logarithm of stock price (sp) as given by $R_{t}=$ $\Delta \log \mathrm{sp}_{t}=\log \left(\mathrm{sp}_{t}\right)-\log \left(\mathrm{sp}_{t-1}\right)$. The monthly percentage changes in the NZX All Stock Index, M1 money supply and international tourist arrivals are proxies for market return, money supply, and international tourism demand, respectively [46-48]. Note that the variable of interest $y_{t}$ is expressed as growth rate or rate of change by taking first difference of $\log y_{t}$ as follows:

$$
\Delta \log \left(y_{t}\right)=\log \left(\frac{y_{t}}{y_{t-1}}\right)=\log \left(1+\left(\frac{\Delta y_{t}}{y_{t-1}}\right)\right) \approx \frac{\Delta y_{t}}{y_{t-1}} .
$$

However, the discount rate variable (proxied by bank bill rate, term premium, and cash rate) is expressed in levels. For instance, the change in the discount rate such as the 90-day bank bill rate (bbr) is defined as difference in levels: $\Delta$ bbr $_{t}=$ $\mathrm{bbr}_{t}-\mathrm{bbr}_{t-1}$.

Descriptive statistics for the explanatory factors are given in Table 3. According to the Jarque-Bera test, normality is not 
TABLE 3: Descriptive statistics of explanatory factors, 1999(3)-2012(9).

\begin{tabular}{lccc}
\hline Factor & Mean & Standard deviation & Normality \\
\hline Return of market portfolio & 0.0568 & 3.686 & 19.53 \\
Change in M1 money supply & 0.5665 & 2.881 & $577.42^{*}$ \\
Change in 90-day bank bill & -0.0123 & 0.218 & 1052.4 \\
Change in term premium & -0.0002 & 0.269 & 43.87 \\
Change in official cash rate & -0.0123 & 0.210 & 3165.38 \\
Change in tourist arrivals & 0.1290 & 19.927 & $3.94^{*}$ \\
\hline
\end{tabular}

Note: ${ }^{*}$ indicates $5 \%$ significance level.

TABle 4: Philip-Perron test statistics.

\begin{tabular}{lcr}
\hline Variable & & Philip-Perron \\
& Without trend (critical value $=-2.88)$ & With trend (critical value $=-3.44$ ) \\
\hline Auckland International Airport & -14.26 & -14.25 \\
Air New Zealand & -9.59 & -9.60 \\
Millenium \& Copthorne Hotels & -13.92 & -13.89 \\
New Zealand Experience & -20.75 & -21.15 \\
Restaurant Brands & -12.62 & -12.62 \\
Sky City Entertainment & -13.60 & -13.65 \\
Tourism Holdings & -11.76 & -11.74 \\
Change in market portfolio & -12.49 & -12.46 \\
Change in M1 money supply & -15.15 & -15.08 \\
Change in 90-day bank bill & -5.18 & -5.29 \\
Change in term premium & -8.71 & -8.69 \\
Change in official cash rate & -6.54 & -6.68 \\
Change in tourist arrivals & -11.22 & -11.18
\end{tabular}

rejected at the 5\% level for the M1 money supply and tourist arrival variables.

4.3. Unit Root Tests. The test for the stationarity of the returns and explanatory factors is the Philip-Perron test which is based on the following regression equation [49]:

$$
\Delta y_{t}=\alpha+\beta t+\delta y_{t-1}+\varepsilon_{t}
$$

where $\Delta y_{t}$ is the change in the variable of interest at time $t$, $t$ is a deterministic time trend, and $\varepsilon_{t}$ is a disturbance term which is independent and normally distributed with zero mean and constant variance. In order to test for unit roots, the hypotheses of interest are

$$
\begin{aligned}
& H_{0}: \delta=0 \\
& H_{1}: \delta<0 .
\end{aligned}
$$

The null hypothesis of a unit root is based on the $t$-statistic (which has a nonstandard distribution) using simulated critical values. According to the Phillips-Perron (PP) unit root tests which are reported in Table 4, the PP statistics with and without trend for stock returns and explanatory factors are all less than the $5 \%$ critical value of -3.44 and -2.88 , respectively. Hence, none of these series have unit roots.

\section{Empirical Results}

The two-step procedure [42] to estimate the influences of the explanatory factors on the hospitality-tourism stock returns is as follows. Initially, we regress time-series stock returns on these variables to estimate factor sensitivities for each stock using ordinary least squares over the period 1999(3) to 2012(9). Accordingly, twenty-one single equations are estimated and the time-series results are presented in Table 5.

In the second stage of the procedure, the estimated factor sensitivities are used as independent variables to explain expected returns (given by the estimated $\alpha$-see (4) and (7)) by cross-section method over the seven stocks. The crosssectional regression for the hospitality-tourism portfolio is run using three models to estimate the size and statistical significance of the factor premiums.

Model 1:

$E\left(R_{i}\right)=\lambda_{0}+\lambda_{1} \widehat{\beta}_{\mathrm{mkt}}+\lambda_{2} \widehat{\beta}_{\mathrm{ms}}+\lambda_{3} \widehat{\beta}_{\mathrm{bbr}}+\lambda_{4} \widehat{\beta}_{\mathrm{int} \_t o u r}$

Model 2:

$E\left(R_{i}\right)=\lambda_{0}+\lambda_{1} \widehat{\beta}_{\mathrm{mkt}}+\lambda_{2} \widehat{\beta}_{\mathrm{ms}}+\lambda_{3} \widehat{\beta}_{\mathrm{tmp}}+\lambda_{4} \widehat{\beta}_{\text {int tour }}$

Model 3:

$E\left(R_{i}\right)=\lambda_{0}+\lambda_{1} \widehat{\beta}_{\mathrm{mkt}}+\lambda_{2} \widehat{\beta}_{\mathrm{ms}}+\lambda_{3} \widehat{\beta}_{\mathrm{ocr}}+\lambda_{4} \widehat{\beta}_{\text {int } \_ \text {tour }}$, 
TABLE 5: Time series estimates of factor sensitivity.

(a) Model 1: using 90-day bank bill rate as discount rate proxy $(n=162)$

\begin{tabular}{|c|c|c|c|c|c|c|c|}
\hline Firm & AIA & AIR & MCK & NZE & $\mathrm{RBD}$ & SKC & THL \\
\hline Expected returns & 0.684 & -1.427 & 0.179 & 1.170 & 0.287 & 0.489 & -0.283 \\
\hline dlog mkt & 0.887 & 1.173 & 0.523 & 0.210 & 0.632 & 1.108 & 1.518 \\
\hline dlog ms & -0.088 & -0.052 & 0.084 & -0.045 & 0.052 & -0.010 & -0.211 \\
\hline Change in bbr & 0.082 & 6.541 & 7.089 & 5.216 & -0.748 & -2.207 & 6.880 \\
\hline dlog Ta & 0.017 & -0.039 & -0.001 & 0.109 & -0.022 & 0.016 & -0.004 \\
\hline Adjusted $R^{2}$ & 0.29 & 0.15 & 0.09 & 0.01 & 0.08 & 0.40 & 0.34 \\
\hline
\end{tabular}

(b) Model 2: using term premium as discount rate proxy $(n=162)$

\begin{tabular}{lccccccc}
\hline Firm & AIA & AIR & MCK & NZE & RBD & SKC & THL \\
\hline Expected returns & 0.686 & -1.507 & 0.080 & 1.048 & 0.309 & 0.531 & -0.366 \\
dlog mkt & 0.885 & 1.217 & 0.577 & 0.275 & 0.620 & 1.086 & 1.564 \\
dlog ms & -0.092 & -0.063 & 0.088 & 0.023 & 0.036 & -0.026 & -0.223 \\
Change in tmp & 0.349 & -1.488 & -3.053 & -7.974 & 1.687 & 2.183 & -1.453 \\
dlog Ta & 0.017 & -0.039 & -0.003 & 0.103 & -0.021 & 0.018 & -0.004 \\
Adjusted $R^{2}$ & 0.29 & 0.14 & 0.06 & 0.02 & 0.09 & 0.40 & 0.32 \\
\hline
\end{tabular}

(c) Model 3: using official cash rate as discount rate proxy $(n=162)$

\begin{tabular}{lccccccc}
\hline Firm & AIA & AIR & MCK & NZE & RBD & SKC & THL \\
\hline Expected returns & 0.676 & -1.432 & 0.142 & 1.070 & 0.283 & 0.505 & -0.305 \\
dlog mkt & 0.891 & 1.171 & 0.541 & 0.270 & 0.635 & 1.100 & 1.527 \\
dlog ms & -0.096 & -0.006 & 0.097 & -0.124 & 0.042 & -0.009 & -0.182 \\
Change in ocr & -0.835 & 8.278 & 4.877 & -6.262 & -1.509 & -0.935 & 6.469 \\
dlog Ta & 0.017 & -0.035 & 0.002 & 0.107 & -0.023 & 0.016 & -0.0002 \\
Adjusted $R^{2}$ & 0.29 & 0.16 & 0.07 & 0.01 & 0.09 & 0.40 & 0.34 \\
\hline
\end{tabular}

where bbr, tmp, and ocr are the 90-day bank bill rate, term premium, and official cash rate, respectively. Using White's [50] covariance estimator, the cross-sectional regressions for the equilibrium expected returns on the hospitality-tourism stock portfolio are (parentheses denote White corrected $t$ statistics).

Model 1:

$$
\begin{aligned}
E\left(R_{i}\right)= & 0.88-0.65 \widehat{\beta}_{\mathrm{mkt}}-0.96 \widehat{\beta}_{\mathrm{ms}}-0.09 \widehat{\beta}_{\mathrm{bbr}}+9.95 \widehat{\beta}_{\mathrm{int} \_t o u r} \\
& (2.15) \quad(1.33) \quad(0.27)
\end{aligned}
$$

Adjusted $R^{2}=0.52$.

Model 2:

$$
\begin{gathered}
E\left(R_{i}\right)=1.35-1.40 \widehat{\beta}_{\mathrm{mkt}}-2.53 \widehat{\beta}_{\mathrm{ms}}+0.18 \widehat{\beta}_{\mathrm{tmp}}+16.52 \widehat{\beta}_{\text {int _tour }} \\
\quad(4.33) \quad(2.61) \quad(0.87) \quad(2.60) \\
\text { Adjusted } R^{2}=0.75
\end{gathered}
$$

Model 3:

$$
\begin{aligned}
E\left(R_{i}\right)= & 0.03+0.30 \widehat{\beta}_{\mathrm{mkt}}+1.32 \widehat{\beta}_{\mathrm{ms}}-0.12 \widehat{\beta}_{\mathrm{ocr}}+5.69 \widehat{\beta}_{\text {int } t \text { tour }} \\
& (0.06) \quad(0.59) \quad(0.44) \quad(1.56)
\end{aligned}
$$

Adjusted $R^{2}=0.44$.
International tourism plays a significant role in explaining the cross-sectional variation of estimated expected returns on the hospitality-tourism portfolio in New Zealand. Note that the tourism sensitivity variable has a significant positive coefficient in models 1 and 2 . The estimated risk premium $\left(\lambda_{4}\right)$ ranges between $9.95 \%$ and $16.52 \%$. Furthermore, the tourism demand risk suggests that the expected excess return (return above the risk-free rate) tends to increase with a positive tourism arrival surprise. A one-unit increase in tourist arrival sensitivity would result in expected return increase of about 10 to 17 percentage point. The tourism variable has the highest risk premium among all the factors investigated.

The market sensitivity variable is statistically significant at the $5 \%$ level in model 2 . We expect stock returns to increase with a positive market return risk premium but it appears that the premium associated with market risk is negative. The discount rate sensitivity also helps explain the cross-sectional variation of expected returns on New Zealand's hospitalitytourism stocks. The risk premium is statistically significant at the $5 \%$ level in model 2 in which the term premium is used as a proxy. This implies that a higher discount rate term premium results in higher future cash flows and higher expected stock returns. The expected return of the hospitality-tourism portfolio tends to increase by about $0.2 \%$ with a one-unit increase in the sensitivity to term premium as shown in model 2. 
Using the intercept $\left(\lambda_{0}\right)$ as an estimate of the risk-free rate, the estimated values are significantly different from zero at the 5\% level in models 1 and 2 . The implied values of the expected returns to the unit-sensitivity portfolio are $0.88 \%$ and $1.35 \%$, respectively. The adjusted $R$-squared values for the three models vary from 0.44 to 0.75 , indicating that $44 \%$ to $75 \%$ of the cross-sectional variation in the expected return of hospitality-tourism portfolio is accounted for by these variables.

\section{Conclusion}

This paper presents the empirical results of stock return performance of several hospitality and tourism-related companies in New Zealand. Detailed analysis of the stocks' risk/return characteristics is discussed using mean, standard deviation, and beta estimates. The descriptive statistics of the sample provided some useful insights into the diverse financial performance of these companies. Furthermore, the beta findings based on the CAPM provided evidence that some stocks are more responsive than others to fluctuations in the market return.

We used the Arbitrage Pricing Theory approach to examine the cross-sectional returns of these stocks over time. Our choice of market, macro, and tourism factors is similar to those used in previous APT studies and Chen $[27,30]$. The time series regressions used natural logs of the variables except for discount rates which are in levels. Although the expected portfolio returns of the hospitality and tourism stocks are not exclusively due to the market, macro, and tourism variables, our findings of the cross-sectional regression models have very good explanatory power.

The research findings offer useful information and some implications for tourism management. First, this study provides valuable insights to investors in understanding the different sources of risk for the expected return on hospitalitytourism stock portfolio. Second, the cross-sectional portfolio evaluation shows that there is a significant relationship between expected returns, market, macro and tourism factors. It is not surprising that these stocks have a high sensitivity to international tourism demand risk. In fact, an increase in tourism demand sensitivity makes the largest contribution to expected return, among the factors under study.

Third, given the high tourism demand priced risk, it is imperative for firms and policymakers to promote inbound tourism through effective marketing and management. This in turn can provide higher expected returns and create shareholder value for investors. Additionally, it is prudent for hospitality and tourism firms to attract more investors to raise capital for future expansion. This is fundamentally important as more companies are turning to capital raising worldwide due to costly borrowing from the international money markets, related to the ongoing concerns about US and Europe's debt problems.

Finally, the study makes a contribution to the hospitalityfinance literature, identifying research gaps and advancing the understanding of hospitality-tourism expected returns based on market, macro, and tourism factor risk premiums.
However, the study has limitations which include the relatively small sample of hospitality and tourism companies used. This is because there are very few such companies listed on the New Zealand stock exchange. Future research using data from different countries can advance our understanding of hospitality-tourism expected returns and factor risk premium as market situations vary from country to country.

\section{References}

[1] World Travel \& Tourism Council, "Progress and Priorities," 2008, http://www.wttc.org/eng/Tourism_Research/Tourism Economic_Research.

[2] World Travel \& Tourism Council, "The Economic Impact of Travel \& Tourism 2012," http://www.wttc.org/site_media/ uploads/downloads/singapore2012.pdf.

[3] D. K. Hayes and A. A. Miller, Revenue Management for the Hospitality Industry, John Wiley \& Sons, New Jersey, NJ, USA, 2011.

[4] N. F. Chen, R. Roll, and S. A. Ross, "Economic forces and the stock market," Journal of Business, vol. 59, pp. 383-403, 1986.

[5] M. H. Chen, "Interactions between business conditions and financial performance of tourism firms: evidence from China and Taiwan," Tourism Management, vol. 28, no. 1, pp. 188-203, 2007.

[6] Auckland Airport, "Annual Report, 2012," http://www.aucklandairport.co.nz/Annual-Report/ /media/Files/Annual\%20 Report/Auckland_Airport_Annual_Report_2012.ashx.

[7] Auckland Airport, "An assessment of the future contribution by Auckland Airport to the Auckland Region and New Zealand Economies," 2010, http://www.aucklandairport.co.nz/Corporate.aspx.

[8] Air New Zealand, "Air New Zealand completes Ansett purchase," NZX Deep Archive database, 2000.

[9] Air New Zealand and Company History, 2006, http://www .airnewzealand.co.nz/resources/company_history_feb_06.pdf.

[10] Air New Zealand, “Company Profile," 2011, http://www .airnewzealand.co.nz/about-air-new-zealand.

[11] Millennium Hotels and Resorts, "Financial library-annual reports," 2009, http://www.millenniumhotels.com/corporate/ investor_relations/annualReport_nz.html.

[12] Millennium Hotels and Resort, "Corporate-Overview," 2009, http://www.millenniumhotels.com/corporate/index.html.

[13] Restaurant Brands, “Annual Report 2010/20111," http://www .restaurantbrands.co.nz/images/stories/Annual_Reports/2011 2012/rbnz_ar11_web.pdf.

[14] New Zealand Experience Limited, “Annual report 1995," NZX Deep Archive database.

[15] New Zealand Experience Limited, "Company Description," 2011, http://investing.businessweek.com/research/stocks/snapshot/snapshot_article.asp?ticker=NZE:NZ.

[16] SKYCITY, "Entertainment Group," http://www.skycityentertainmentgroup.com/About-SKYCITY/Welcome.html.

[17] Tourism Holdings Limited, “Annual Report 2008," http://www .thlonline.com/CentralLibraryDocuments/Corporate/AnnualInterim-Reports/Annual\%20Report\%202008.pdf.

[18] Tourism Holdings Limited, "Company Profile," 2011, http:// www.thlonline.com/THLBusinesses/default.aspx.

[19] S. A. Ross, “The arbitrage theory of capital asset pricing," Journal of Economic Theory, vol. 13, no. 3, pp. 341-360, 1976. 
[20] N. F. Chen, "Some empirical tests of the theory of arbitrage pricing," Journal of Finance, vol. 38, no. 5, pp. 1393-1414, 1983.

[21] M. Beenstock and K. Chan, "Economic forces and London Stock Market," Oxford Bulletin of Economics and Statistics, vol. 50, pp. 27-39, 1988.

[22] R. Priestley, "The arbitrage pricing theory, macroeconomic and financial factors, and expectations generating processes," Journal of Banking and Finance, vol. 20, no. 5, pp. 869-890, 1996.

[23] N. Groenewold and P. Fraser, "Share prices and macroeconomic factors," Journal of Business Finance and Accounting, vol. 24, no. 9-10, pp. 1367-1383, 1997.

[24] H. Rjoub, T. Türsoy, and N. Günsel, "The effects of macroeconomic factors on stock returns: Istanbul stock market," Studies in Economics and Finance, vol. 26, no. 1, pp. 36-45, 2009.

[25] C. W. Barrows and A. Naka, "Use of macroeconomic variables to evaluate selected hospitality stock returns in the U.S.", International Journal of Hospitality Management, vol. 13, no. 2, pp. 119-128, 1994.

[26] M. H. Chen, W. G. Kim, and H. J. Kim, "The impact of macroeconomic and non-macroeconomic forces on hotel stock returns," International Journal of Hospitality Management, vol. 24, no. 2, pp. 243-258, 2005.

[27] M. H. Chen, "Hotel stock performance and monetary conditions," International Journal of Hospitality Management, vol. 26, no. 3, pp. 588-602, 2007.

[28] M. H. Chen, "Macro and non-macro explanatory factors of Chinese hotel stock returns," International Journal of Hospitality Management, vol. 26, no. 4, pp. 991-1004, 2007.

[29] M. H. Chen, "The economy, tourism growth and corporate performance in the Taiwanese hotel industry," Tourism Management, vol. 31, no. 5, pp. 665-675, 2010.

[30] M. H. Chen, "Federal Reserve monetary policy and US hospitality stock returns," Tourism Economics, vol. 16, no. 4, pp. 833-852, 2010.

[31] K. K. F. Wong and H. Song, "Do macroeconomic variables contain any useful information for predicting changes in hospitality stock indices?" Journal of Hospitality \& Tourism Research, vol. 30, no. 1, pp. 16-33, 2006.

[32] F. A. Kwansa, "Acquisitions, shareholder wealth and the lodging sector: 1980-1990," International Journal of Contemporary Hospitality Management, vol. 6, no. 6, pp. 16-20, 1994.

[33] D. H. Chen and F. S. Bin, "Effects of legislation events on US gaming stock returns and market turnings," Tourism Management, vol. 22, pp. 539-549, 2001.

[34] C. Wang and $\mathrm{H}$. Xu, "Government intervention in investment by Chinese listed companies that have diversified into tourism," Tourism Management, vol. 32, no. 6, pp. 1371-1380, 2011.

[35] J. L. Nicolau, "Assessing new hotel openings through an event study," Tourism Management, vol. 23, pp. 47-54, 2002.

[36] M. H. Chen, S. C. Jang, and W. G. Kim, "The impact of the SARS outbreak on Taiwanese hotel stock performance: an event-study approach," International Journal of Hospitality Management, vol. 26, no. 1, pp. 200-212, 2007.

[37] J. G. Choi, M. D. Olsen, F. A. Kwansa, and E. C. Y. Tse, "Forecasting industry turning points: the US hotel industry cycle model," International Journal of Hospitality Management, vol. 18, no. 2, pp. 159-170, 1999.

[38] H. Kim and Z. Gu, "Risk-adjusted performance: a sestor analysis of restaurant firms," Journal of Hospitality and Tourism Research, vol. 27 , pp. 200-216, 2003.
[39] J. S. Lee and S. C. Jang, "The systematic-risk determinants of the US airline industry," Tourism Management, vol. 28, no. 2, pp. 434-442, 2007.

[40] R. W. Faff, "An Empirical test of the arbitrage pricing theory on Australian stock returns 1974-85," Accounting and Finance, vol. 28, pp. 23-43.

[41] T. E. Copeland, J. F. Weston, and K. Shastri, Financial Theory and Corporate Policy, Addison Wesley, Boston, Mass, USA, 4th edition, 2005.

[42] R. A. DeFusco, Quantitative Investment Analysis, John Wiley \& Sons, New Jersey, NJ, USA, 2nd edition, 2007.

[43] R. Roll and S. A. Ross, "An empirical investigation of the arbitrage pricing theory," The Journal of Finance, vol. 35, pp. 1073-1103, 1980.

[44] E. F. Fama and K. R. French, "Business conditions and expected returns on stocks and bonds," Journal of Financial Economics, vol. 25, no. 1, pp. 23-49, 1989.

[45] G. R. Jensen, J. M. Mercer, and R. R. Johnson, "Business conditions, monetary policy, and expected security returns," Journal of Financial Economics, vol. 40, no. 2, pp. 213-237, 1996.

[46] Reserve Bank of New Zealand, http://www.rbnz.govt .nz/statistics/.

[47] Datastream, Equities, Thomson Reuters, New York, NY, USA.

[48] Statistics New Zealand, "Tourist Arrivals," http://www.stats .govt.nz/.

[49] P. C. B. Phillips and P. Perron, "Testing for a unit root in time series regression," Biometrika, vol. 75, no. 2, pp. 335-346, 1988.

[50] H. White, "A hteroskedasticity-consistent covariance matrix and a direct test for heteroskedasticity," Econometrica, vol. 48, pp. 817-838, 1980. 


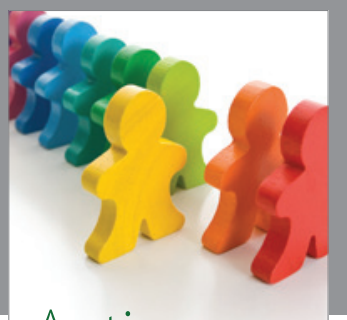

Autism

Research and Treatment
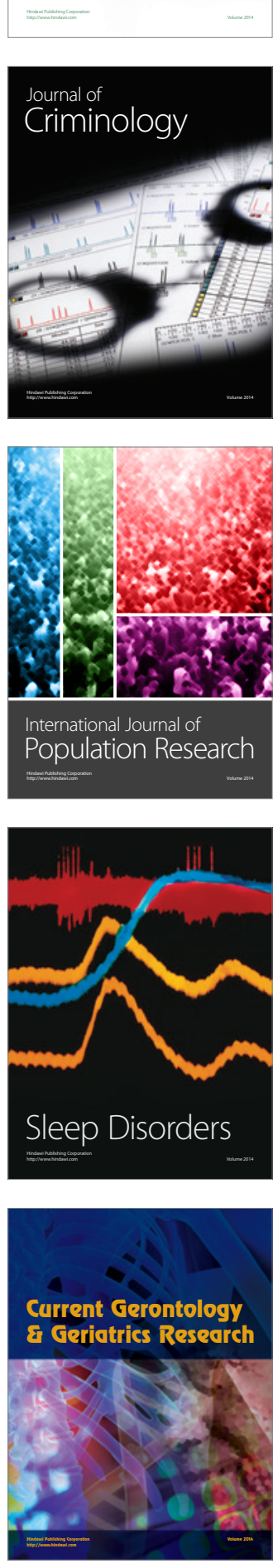
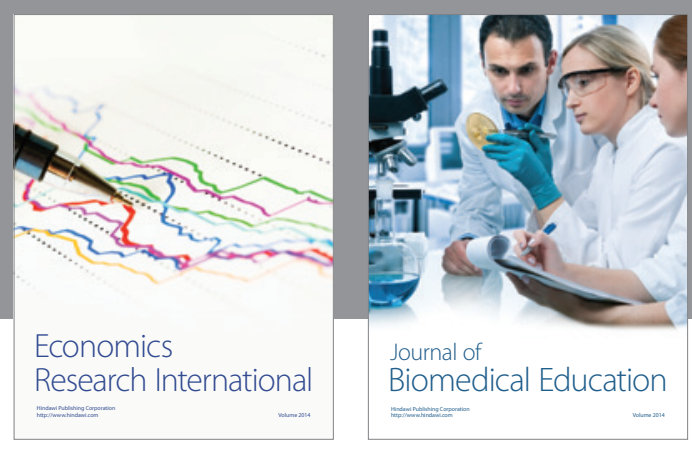

Journal of

Biomedical Education

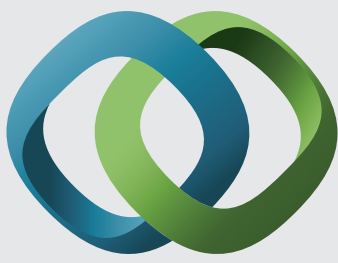

\section{Hindawi}

Submit your manuscripts at

http://www.hindawi.com
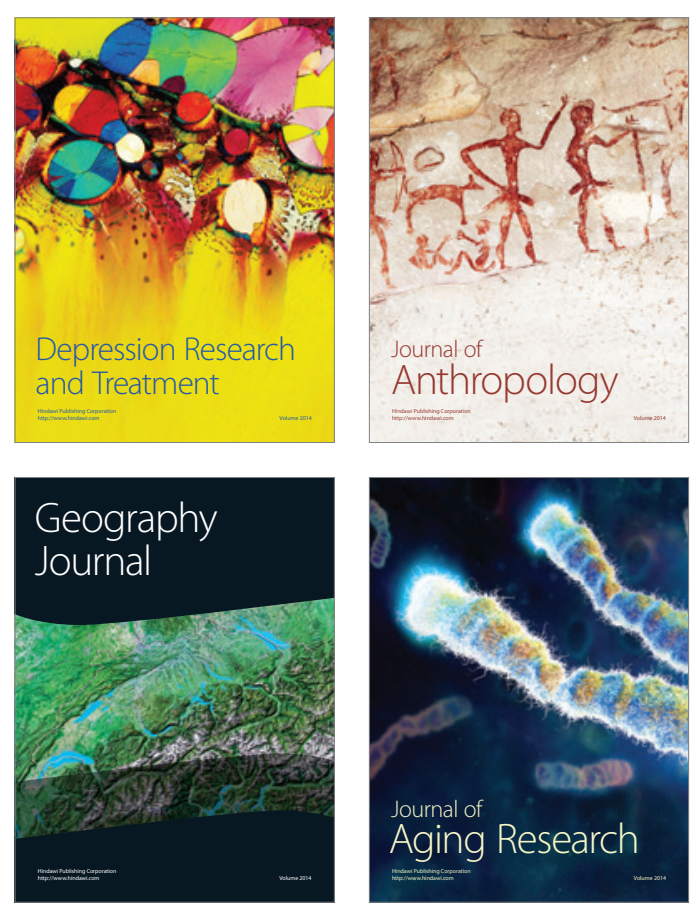

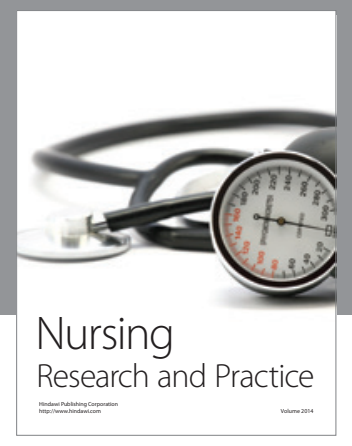

Nursing

Research and Practice

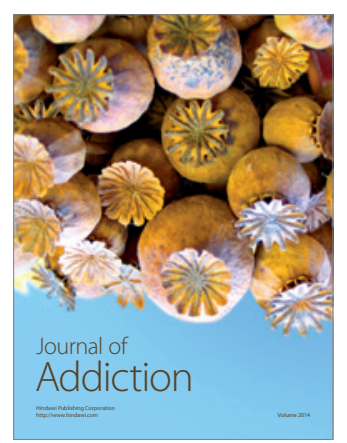

Child Development

Research

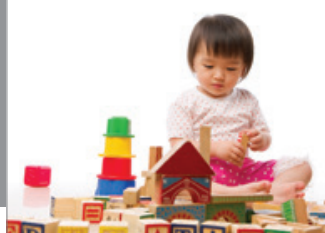

迥
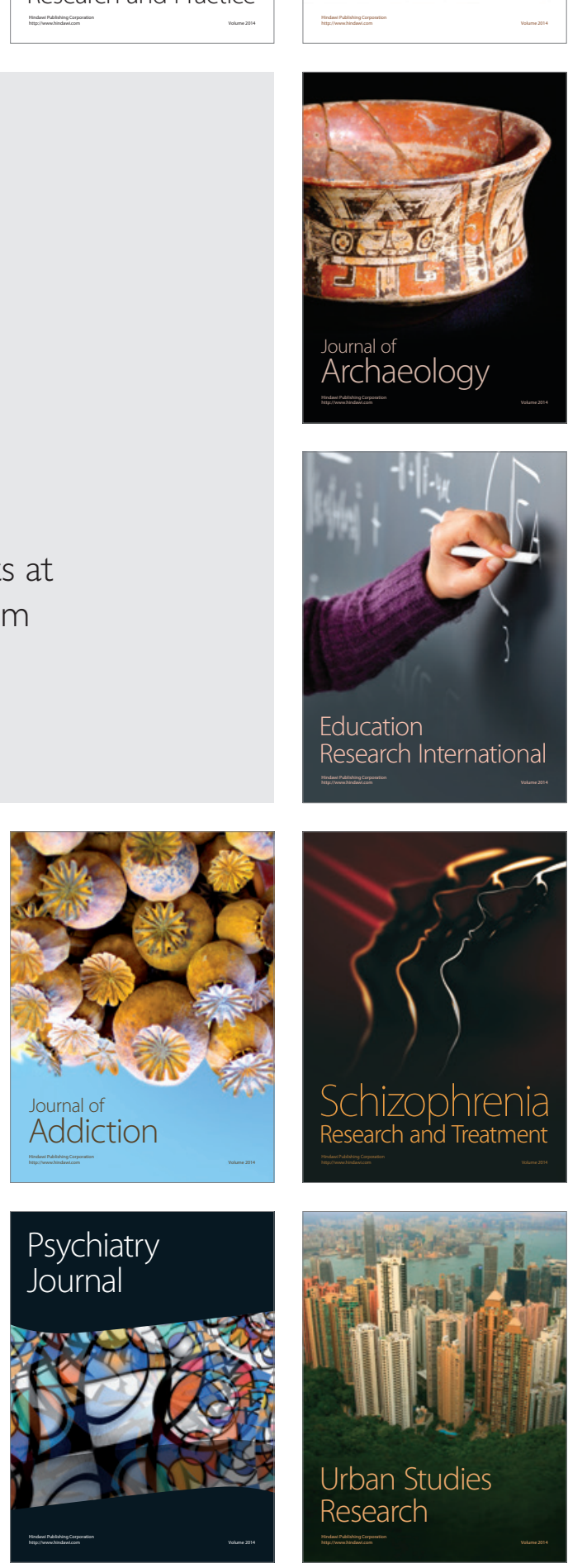